\title{
OUTLIERS OF THE MAXVILLE LIMESTONE IN OHIO NORTH OF THE LICKING RIVER.*
}

\author{
By G. F. Lamb. \\ (Published by permission of the Ohio Geological Survey.)
}

It is well known to those familiar with Ohio geology that the Maxville limestone is the uppermost formation of the Mississippian system found in the Ohio scale, that its outcrop is limited in extent, patchy in character, and that the overlying Pennsylvanian beds rest upon it unconformably.

William C. Morse, in Bulletin 13 of the Ohio Geological Survey, published in 1910, presents the most complete account of this formation published. It is shown in this bulletin that up to 1910 all the known outcrops of this formation occur south of the Licking River, extending from a point a little southwest of Zanesville, on the north, to the vicinity of Portsmouth on the Ohio River. It is further shown that the most. important area of outcrop lies at the north and extends from near Zanesville southward to the vicinity of Logan-an area about 25 miles long and 10 or 12 miles wide.

It has long been supposed that this formation once extended to the northern part of the state and was removed by postMaxville pre-Pennsylvanian erosion. The supposition was based upon the presence of lime cobblestones more or less. silicified found at the bottom of the Coal Measure basal conglomerate, and which were said to carry Mississippian fossils. Since no other Mississippian limestone was known to occur in the state, it was concluded the cobbles must have been derived from the Maxville.

It is the purpose of this paper, (1) to point out the northward extension of this limestone, (2) to throw further light on the origin of the cobble stones, and (3) to emphasize a reason for its absence in the northern part of the state.

The writer has found various outcrops of this limestone as. far as 40 miles north of Zanesville in a belt 10 to 12 miles wide extending northward across Muskingum, Coshocton and into southern Holmes County. They invariably occur in isolated

\footnotetext{
*Read before Section $\mathrm{E}$ of the American Association for the Advancement of Science, Columbus meeting, 1915.
} 
places, and not more than three of the outcrops could be other than outliers.

A few of these outcrops may be described briefly. About 7 miles northwest of Zanesville on the north side of the Licking River and about 11 miles north of the Fultonham outcrops described by Morse, two outcrops were found well exposed in ravines about $3 / 4$ mile apart. The limestone is bluish gray, fine grained, compact, without prominent bedding planes and 3 to 7 feet in thickness. No fossils were found, and it appears to be the lower division of the Maxville described by Morse. Apparently it rests conformably upon the Logan shale, but is overlain unconformably by Coal Measure sandstone.

It was again found in bed north of the Walhonding River, $21 / 2$ miles north of Walhonding Village and 2 miles south of the village of Tiverton Center in northwestern Coshocton County. There six feet of the limestone is well exposed in a deep ravine, contains considerable iron, weathers to the color of yellow clay-indeed almost to the yellow of ochre. The top and bottom weather to a brown. It looks so very like a compact yellow clay that one's first impression of it is that it really is a bed of clay. Digging into the yellow mass 4 to 6 inches dispels the illusion by finding the familiar fine grained light gray limestone. The upper surface as seen in the ravine side is uneven and is overlain by 2 feet of light green mud mingled with flinty cobbles of limestone. The mud bed appears to be the residual material of the decomposing limestone.

Resting directly upon the mud bed is the pebbly Coal Measure rock. This peculiar green mud carrying angular cobble stones, and the underlying limestone weathering to an ochre color is very like exposures found by Morse far to the southward.

Eight miles southeast of the above exposure is the town of Warsaw. Several outcrops occur at 1 to 4 miles north and east of this place which range from 2 to 9 feet in thickness. Two miles east of Warsaw an outcrop presents the ochre weathering phase in marked degree. Four miles east of Warsaw and 6 miles northwest of Coshocton in the high bluff overlooking the junction of Killbuck Creek and Walhonding River occurs the most easterly outcrop found. Three feet of hard gray limestone in several layers weathering brown are exposed and with neither top nor bottom seen. 
Probably one of the most instructive outliers found occurs 4 miles north of Warsaw and 1 mile south-west of Blissfield on the Blissfield-Warsaw highway. The exposure occurs in the highway at the crest of the ridge and shows 9 feet of the limestone in many layers resting conformably upon the Logan shale a long section of which is exposed. Resting directly upon the limestone is a bed of sandstone 12 to 18 inches thick, sharply undulating, and strikingly unconformable. The sandstone is white to gray in color, very compact, and exceedingly hard. The limestone is well weathered, is soft, buff to yellow in color, and contains many fossils of brachipods and fenestellid bryozoans. When completely weathered, as seen in the roadway nearby, it becomes an ocherous earth.

One of the most interesting facts is the presence of hard concretionary nodules more or less silicified and definitely embedded in the limestone. They are precisely like the thousands of loose cobble stones seen in dozens of places where no bed of limestone was found. The writer had believed for some time that where beds of these loose cobbles were found, or where they were numerous, they marked the place of the Maxville limestone, but up to the finding of this outcrop he had no positive evidence of their origin.

It may be pointed out that this outcrop marks the crest of a Mississippian hill, as these patches usually do. North, east, and south the Mississippian surface falls a hundred feet or more. In a hill close by, the Lower Mercer limestone is found only 50 feet above the Maxville-an interval that is usually 120 to 150 feet between the Lower Mercer limestone and the base of the Pennsylvanian.

Noting the elevation at which the various outcrops occur, it is found they all lie in one plane very gently dipping to the south-east. It may be stated further that the many beds of cobble stones found at the Mississippian-Pennsylvanian contact all lie in this same plane. This indicates in no uncertain way that the cobble beds are the remains of the Maxville and mark its place.

The most westerly point at which a bed of cobbles was found is in Licking County, 8 miles north-east of Newark and 4 miles north-west of Hanover. The exposure is in the roadway on the western edge of Perry Township. The stones range in size from the fist up to 15 or 18 inches in diameter, are 
generally flinty in character, weather white, and are fossiliferous. This description will apply to all the cobble beds except in point of size.

The most northerly beds found occur about 5 miles south of Glenmont in Holmes County, where the surface in places is strewn with cobbles. At one point on top of a ridge, besides the cobbles the soil is all a rich chocolate color. The area is an acre or two in extent and is the residue of the fully weathered limestone.

It is now known that the Maxville is found two-thirds of the distance across the state with strong probability of still further extent formerly.

Taking the Berea sandstone as a datum plane in the general direction of the Maxville outcrop, it is found that the BereaMaxville interval increases northward. In Vinton County the interval between the top of the Berea and the top of the Maxville is about 650 feet; at Rushville, in eastern Fairfield County, about 800 feet; at New Castle, in Coshocton County, 840 feet; near Killbuck in southern Holmes County, 870 feet; and 20 miles north of the last point in central Wayne County east of Wooster, 900 feet of shale and sandstone above the Berea does not quite reach the Maxville horizon. Northward from Wayne County the total thickness of the Mississippian strata decreases notably, due to greater erosion in late Mississippian time. In north-eastern Ohio the Pennsylvanian beds lie, commonly, only about 3 to 4 hundred feet above the Berea, and in the old Mississippian river valleys, clearly defined in this area, the Sharon Conglomerate sometimes lies but 100 feet above the Berea.

If the plane of the Maxville be projected northward to Cleveland with the slowly increasing interval between it and the Berea, the Maxville would lie about 1050 feet above the Berea.

In the light of these facts it is apparent that the Maxville can not be found in northern Ohio, and that outcrops may not be expected beyond northern Holmes, or central Wayne County.

It will be noted further that these figures reveal the interesting fact that the Mississippian System thickens northward, although thinest in the northern part of the state now, as a result of greater erosion.

Mt. Union College, Alliance, Ohio. 